\title{
Contextualized Class Improves Perception of Students About Spectrophotometry in Biochemistry Laboratory Practices
}

\author{
Carlos Roberto Porto Dechandt ${ }^{1}$, Caroline Arruda², Carem Gledes Vargas Rechia², Carolina \\ Patrícia Aires ${ }^{2 *}$ \\ ${ }^{1}$ Faculdade de Medicina de Ribeirão Preto da Universidade de São Paulo \\ ${ }^{2}$ Faculdade de Ciências Farmacêuticas de Ribeirão Preto da Universidade de São Paulo
}

* Autora para correspondência: airescp@fcfrp.usp.br

\section{RESUMO}

As aulas práticas ocupam uma considerável proporção do tempo dos estudantes do curso de Farmácia. Assim, torna-se vital que os alunos dos cursos de saúde participem de aulas laboratoriais que os remetam a uma aplicação prática. Entretanto, os estudantes têm dificuldade em correlacionar o conhecimento adquirido em outras disciplinas - especialmente Química Analítica - com Bioquímica. Neste trabalho, utilizou-se uma aula prática existente (tradicional) e uma aula prática contextualizada com um caso clínico, seguida de uma orientação dinâmica sobre espectrofotometria como análise de rotina em pesquisa científica. Com este objetivo, um grupo de estudantes foi submetido à aula prática tradicional (grupo controle, $n=65$ ) enquanto outro foi submetido à aula prática contextualizada (grupo experimental, $n=30$ ). Após a avaliação prática, as pontuações de ambos os grupos foram comparadas entre si. Os resultados sugerem que a contextualização das aulas práticas fornece condições para que os alunos adquiram competência técnica, aumentando sua compreensão acerca da relevância de conceitos interdisciplinares e suas aplicações.

Palavras-Chave: Dificuldade de Aprendizagem, Bioquímica, Curva de Calibração.

\begin{abstract}
Practical work in the laboratory occupies a considerable proportion of students' time in Pharmacy courses. Thus, it is vital for students who are taking courses in health science to experience handling practices thinking about its practical application. However, students have difficulty in correlating the knowledge acquired in other disciplines - especially, Analytical Chemistry - to Biochemistry. Here, we use an existing laboratory practice and contextualized it using a case-oriented examination and a dynamic discussion about spectrophotometry as a routine analysis in scientific research. With this goal, a group of students was submitted to a traditional practical class (control group, $\mathrm{n}=65$ ) while another one was submitted to an contextualized practical class (experimental group, $n=30$ ). After a practical test, the scores of both groups were compared to each other. The results suggested that the contextualization of the practical classes could provide conditions to obtain technical competence of the students, increasing their comprehension about the relevance of interdisciplinary concepts and its applications.
\end{abstract}

Keywords: Learning Difficulties; Biochemistry; Calibration Curve.

\section{Introduction}

Practical work in the laboratory occupies a considerable proportion of students' time in Pharmacy courses. Thus, it is vital for students taking courses in health science to experience handling practices thinking about its practical application. However, students have some difficult to present a clear view of this issue and to correlate concepts from other disciplines, such as spectrophotometry (DE ANDRADE et al., 2017, pp. 24-39).

Spectrophotometric analysis is essential for determining the biomolecule concentration of a solution and is employed ubiquitously in biochemistry using a calibration curve (TRUMBO et al., 2013, pp. 242-250). The application of the BeerLambert-Bouguer Law is routinely used to determine the concentration of protein or carbohydrate 
in practical classes of biochemistry (STRONG, 1952, pp. 338-342). However, students did not realize the importance of this analytical tool in their routine as a pharmacist. In this context, students tend to simply follow an explicit set of instructions to obtain results from calibration curve without create attitudes to solve problems (ADAMS \& WIEMAN, 2011, pp. 1289-1312; ANDERSON \& SCHÖNBORN, 2008, pp. 309-379).

Problem-solving abilities and experimental design are important skills for any pharmaceutical and when worked aligned, theory and practice can open scope and contribute for lab skills at the same time (ALLCHIN, 2013, pp. 364-392; MEHLER, 1983, pp. 95-118; QUITADAMO \& KURTZ, 2007, pp. 140-154). Thus, the contextualization of the lecture material and practical application of the calibration curve can contribute to improve how learning is carried out. This study problem is focused in finding out the influence of contextualizing a practical class on the students' practice concepts improvement in comparison with their colleagues who benefit from this curriculum through traditional practical classes (ANWAR et al., 2017; DUNLOSKY et al., 2013, pp. 4-58).

\section{Methodology}

The biochemistry laboratory course has enrollments of 30-70 students per semester, who are divided into groups of three to four students each. The students work within the same group except for the practical test, in which they work in pairs. The students enrolled in the first semester of 2017 $(\mathrm{n}=65)$ participated of a traditional practical class, while that ones enrolled in the second semester of 2017 ( $\mathrm{n}=30$, control group) were involved in an contextualized practical class (experimental group). The variables were controlled, which means that both courses are equivalent in terms of specialty, academic level, teacher and teaching location.

An existing laboratory practice implemented successfully in previous years was used to conduct this class, which consisted of carbohydrates quantification using spectrophotometry analysis. For the traditional practical class, a protocol containing experimental goals and general principles behind the procedures were handed out to the students one week before the class. After the professor explain the objectives of the class and deals with possible questions, a practical class begins with a revision of a flow chart presented by each student before starting the experiments. For the contextualized practical class, the same activities settled by the traditional practical class were applied but the proposal was introduced using: i) a case-study examination: the construction of such case was motivated by a problem of blood glucose levels in an adolescent. The students were required to solve the blood analysis using spectrophotometry and values of standard curve and blood sample were delivered to them at the beginning of the semester; ii) a dynamic presentation of two graduate students about the use of spectrophotometry in routine scientific analysis. The presentation included routine uses of spectrophotometry in order to generate and sustains interest, attention and critical thinking of learners.

Two weeks after the practical class, both groups of students (traditional and contextualized practical class) were submitted to a practical test, where academics were challenged to use spectrophotometry to quantify carbohydrate or protein in two unknown samples. Knowledge assessment of the groups was performed according to the student's grade (ANWAR et al., 2017; DALE, 1946; WALKER \& RAPLEY, 2008), which had a maximum value of 1.0 and the results were compared.

\section{Results and Discussion}

In our teaching experience, we have noticed that the students are underprepared to work successfully in a bench work situation using a calibration curve to quantify macromolecules in the Biochemistry course. There are a number of reasons that can explain this lack of preparation, but the major one is a lack of effective thinking about the skill acquired during previous disciplines (EILKS \& HOFSTEIN, 2015; GUPTA, 2012). In order to help students to better 
understand the expectations of the teaching class and to help them to think about how to correlate the principles of spectrophotometry to the biochemistry activities, we've used an existing laboratory practical and contextualized it using a case-oriented examination and a dynamic discussion about spectrophotometry as a routine analysis in scientific research.

As shown in Figure 1, when exposed to traditional class, $87 \%$ of the students scored lower than 0.5 [63\% lower than $0.25 ; 24 \%$ higher than 0.25 ], and only $13 \%$ of the students showed grades higher than $0.5[6.5 \%$ lower than $0.75 ; 6.5 \%$ higher than 0.75$]$. In contrast, regarding the students who have been exposed to the contextualized practical class, $54.1 \%$ of the students scored lower than 0.5 [12.5\% lower than $0.25 ; 41.6 \%$ higher than 0.25$]$, and $45.9 \%$ higher than $0.5[16.6 \%$ lower than $0.75 ; 29.3 \%$ higher than 0.75$]$.

\section{Conclusion}

Our results indicate that the contextualization of the practical classes can provide technical competence to the students, increasing their comprehension about the relevance of interdisciplinary concepts. Experimental work with problem challenges linked with the students' career makes learning relevant for them, and it is expected that they will engage in class. This result demonstrated the benefits of meaningful learning experiences in the practical biochemistry course. The students' learning is significant when they are motivated and able to correlate the acquired knowledge.

\section{References}

ADAMS, Wendy. K. \& WIEMAN, C. E. "Development and Validation of Instruments to Measure Learning of Expert-Like Thinking". International Journal of Science Education, vol. 33, n.9, 2011, pp. 1289-1312.

ALLCHIN, Douglas. "Problem- and Case-Based Learning in Science: An Introduction to Distinctions, Values, and Outcomes". Cell Biology Education, vol. 12, n. 3, 2013, pp. 364-372.

ANDERSON, Trevor R. \& SCHÖNBORN, K. J. "Bridging the educational research-teaching practice gap". Biochemistry and Molecular Biology Education, vol 36, n.4, 2008, pp. 309-379.

ANWAR, Yunita Arian Sani., SENAM, \& LAKSONO, E. W. "Identification of the students' critical thinking skills through biochemistry laboratory work report". AIP Conference Procedures, v. 1868, 2017, pp. 30013.

DALE, Edgar. "Audio-visual methods in teaching". New York: Dryden Press, 1946.

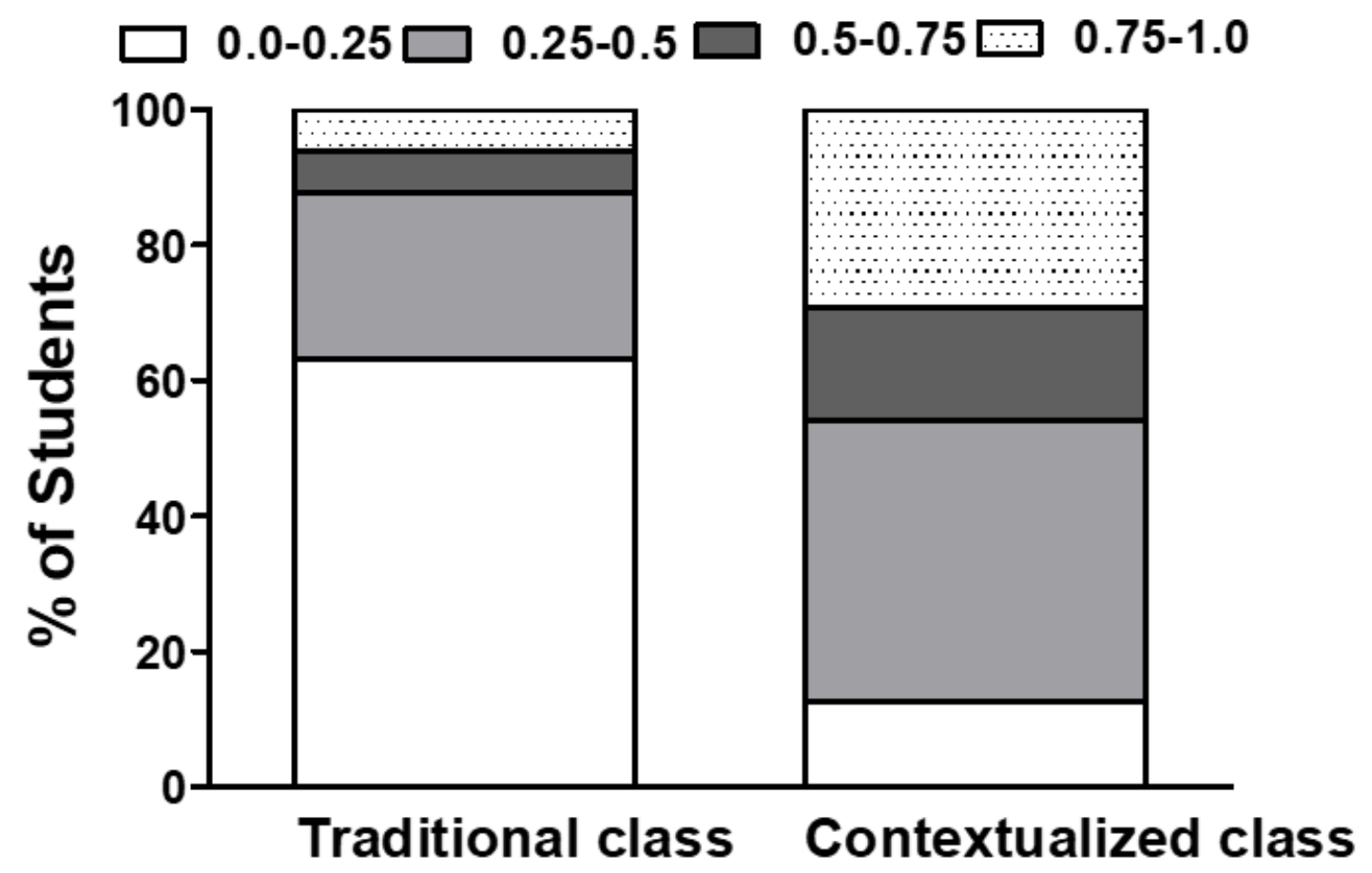

Figure 1 - Students' grades according the different classes used in this study. 
DE ANDRADE, Raíssa Silva Bacelar; E SILVA, A. F. D. S.; ZIERER, M. D. S. "Avaliação das dificuldades de aprendizado em Bioquímica dos discentes da Universidade Federal do Piauí." Revista de Ensino de Bioquímica, vol. 15, n.1, 2017, pp. 24-39.

DUNLOSKY, John; RAWSON, K. A.; MARSH, E. J.; NATHAN, M. J.; WILLINGHAM, D. T. "Improving Students' Learning With Effective Learning Techniques. Psychological Science in the Public Interest", vol. 14, n.1, 2013, pp. 4-58.

EILKS, Ingo, \& HOFSTEIN, A. "Relevant Chemistry Education". Rotterdam: SensePublishers, 2015.

GUPTA, T. "Guided-inquiry based laboratory instruction: investigation of critical thinking skills, problem solving skills, and implementing student roles in chemistry". Dissertation (Doctor in Philosophy) Iowa State University, 2012.
MEHLER, Alan. H. "Strategies of biochemical education. Biochemical Education", vol. 11, n.3, 1983, pp. 95-118.

QUITADAMO, Ian.J. \& KURTZ, M. J. "Learning to Improve: Using Writing to Increase Critical Thinking Performance in General Education Biology". Cell Biology Education, vol. 6, n.2, 2007, pp.140-154.

STRONG, Frederick. C. "Theoretical Basis of Bouguer-Beer Law of Radiation Absorption". Analytical Chemistry, vol. 24, n.2, 1952, pp. 338-342.

TRUMBO, Toni. A.; SCHULTZ, E.; BORLAND, M. G.; PUGH, M. E. "Applied spectrophotometry: Analysis of a biochemical mixture". Biochemistry and Molecular Biology Education, vol. 41, n.4, 2013, pp. 242-250.

WALKER, John. M. \& RAPLEY, R. "Molecular Biomethods Handbook". (J. M. Walker \& R. Rapley, Eds.). Totowa: Humana Press. 2008.

Publicado em 04/07/2018. 